\title{
バイリニア型履歴系の地震応答に及ぼす減衰の影響 EFFECT OF DAMPING ON SEISMIC RESPONSE OF BILINEAR HYSTERETIC SYSTEMS
}

\author{
松 島 豊* \\ Yutaka MATSUSHIMA
}

\begin{abstract}
The nonlinear random response of the single-degree-of-freedom system having the elasto-plastic hysteretic restoring force together with the viscous damping is presented. The Gaussian white noise is assumed as the ground acceleration. Two types of damping where the coefficient of viscousity is taken proportional to the elastic stiffness and to the instantaneous stiffness are dealt with. The analysis aims at finding the approximate solutions for the expectation and the variance of displacement, velocity, ductility factor, cumulative ductility factor and damping energy. The solutions are compared and well agree with the digital estimates in many cases.
\end{abstract}

Keywords : nonlinear response, random response, viscous damping, bilinear hysteresis, white noise, seismic design

非線形応答, ランダム応答, 粘性诚衰, バイリニア履歴, 白色雑音, 耐震設計

\section{1. 序}

筆者は文献 1）で非減衰のバイリニア型履歴 1 自由度 系にホワイトノイズが地動として作用した場合の非線形 ランダム応答を考察した。そこでは変位応答を履歴中心 の移動量とその中心まわりの変位から成るものとした。 前者を正負の累積塑性変形の差に基づくランダムウォ一 クとみなし，後者を振動する成分としてその固有振動数 を評価した。変位と速度の分散, 最大变形と累積塑性変 形の期待值と分散も閉じた形の単純な関数で表現し，そ れらが数值実験值とよく一致することを確認した。

本論文でもこの方法をそのまま踏襲し，同じ完全弾塑 性型のバイリニア嚄歴特性をもつ 1 自由度系にホワイト ノイズが作用する場合を扱うが，系には速度に比例する 粘性減衰があるものとする。減衰の型としては粘性減衰 係数か弾性剛性に比例する場合と，時間とともに変わる 局所的な剛性，いわゆる瞬間剛性に比例する場合の 2 種 類を想定する。構造物の応答解析や耐震設計では多く前 者が仮定されるが，ときには後者が採用されることもあ る。同し減衰定数が用いられても, 減衰の型が異なると 応答は変化する。その差を解析的に求めた研究はほとん ゼないので，ここではとくに減衰の大きさと型が応答に どのような影響を及ぼすかに注目する。実際の構造物に 付与されている減衰の機構がどちらの型に近いかという ことには触れない。それはまた別の課題である。関連す
る他の既往の研究で採られている方法と本論の方法との 関係については文献 1) で詳述されているので再録しな い。

变位と速度の分散; 塑性率, 累積塑性率および減衰工 ネルギーの期待値と分散を単純な関数で表現する。解の 妥当性はモンテカルロ・シミュレーションによる数値実 験によって検証される。サンプルサイズが大分大きけれ ば, 数值実験值は正解に近づくので, これもできるだけ 実用的な形でとりまとめる。

\section{2. 入出力系}

静止している粘性減衰をもつ 1 自由度系の基部に, 突 然ガウス型ホワイトノイズが地動加速度として作用する 場合を扱う。粘性減衰には弾性剛性に比例するものと瞬 間剛性に比例するものの 2 つ型を考える。前者は娍衰 力 $c \dot{x}$ において, 粘性減衰係数 $c$ が $\left(2 h / \omega_{0}\right) k_{0}=$ $2 h \omega_{0} m$ となるものをいう。ここで $h$ は诚衰定数, $k_{0}(=$ $\left.\omega_{0}^{2} m\right)$ は弾性剛性, $\omega_{0}$ は弾性時の固有角振動数, $m$ は 質量である。以後簡単のためにこれを線形減衰と呼ぶ。 後者は $k_{t}$ を瞬間剛性としたとき, $c=\left(2 h / \omega_{0}\right) k_{t}$ とな るものをいう。以後これを非線形诚衰と呼ぶ。力の釣合 いより，単位質量あたりの運動方程式が次のように得ら れる。

$$
\ddot{x}+2 h \omega_{t} \dot{x}+f(x, \dot{x})=-U(t) W(t)
$$

* 筑波大学構造工学系 教授. 工博
Prof., Institute of Engineering Mechanics, Univ. of Tsukuba, Dr. Eng. 
ここで, $x$ は質点の変位，・は時間 $t$ に関する微分を 表す。 $U(t)$ は単位階段関数, $W(t)$ は一定スペクト ル密度 $S_{0}$ をもつ平均值ゼロの定常ホワイトノイズとす る。 $f(x, \dot{x})$ は復元力関数を表し, 完全弾塑性型のバ イリニア履歴をもつものとする。降伏変位を $\Delta$ とし， 降伏加速度 $\alpha\left(=\omega_{0}^{2} \Delta\right)$ で完全な塑性流れを起こす。線 形减衰では $\omega_{t}$ は常に一定值 $\omega_{0}$ に等しい。非線形減衰 では応答が $\omega_{0}^{2}$ の勾配をもつ第 1 分枝上にあるとき $\omega_{t}=$ $\omega_{0}$, 勾配がゼ口の第 2 分枝上にあるとき $\omega_{t}=0$ とする。

\section{3. 応答が弾性限に達する期待時間}

(1) 式の初期条件は， $t=0$ で $x=\dot{x}=0$ 上する。応 答は非定常となり, 系はある時間内では弾性的に挙動す る。弾性限界に達するまでの時間の期待値 $t_{0}$ は近似的 に次のようにして求められる。

弾性変位の最大值の期待值は,

$$
|\bar{\eta}|_{\max }=a \sigma_{\eta}
$$

と書ける。ここで， $\eta$ は降伏変位で規準化された変位 $x / \Delta$ を表す。上つきの一は期待値， $\sigma$ は標準偏差を表 す。 $a$ の值は近似的に次式で表される。

$$
a=\sqrt{2} f(h \tau)
$$

ここで,

$$
f(h \tau)=\sqrt{0.424+\ln (4 \pi h \tau+1.78)}
$$

$\tau$ は弾性時の固有周期 $T_{0}$ で規準化された時間 $t / T_{0}$ を 表す。(4) 式で与えられる関数は， $h=0$ のとき $1, h$ >0で1より大きくなるもので, Rosenbluethらによる 減衰応答の補正係数 ${ }^{21}$ に相当している。

$\sigma_{n}$ は近似的に次式で与えられる。

$$
\sigma_{\eta}=\sqrt{\frac{\pi \xi}{2 h}\left(1-e^{-4 \pi h \tau}\right)}
$$

ここで, $\xi \equiv \omega_{0} S_{0} / \alpha^{2}$ である。 $\xi$ は構造物の強度に対す る入力の強度の比に相当する無次元量である。

$\tau_{0} \equiv t_{0} / T_{0}$ は $|\bar{\eta}|_{\max }=1$ となるような時間であり, ( 3 ) （5) 式より $a \sigma_{\eta}=1$ を満足する $\tau$ の值として求㛣 れる。この方程式はてに関して陽には解けないので, 解を得るには反復計算が必要である。ただし, 通常使わ れる $\xi$ と $h$ 範囲, 例えば, $\xi \geqq 0.025, h \leqq 0.1$ では $\tau_{0}$ はおおむね 1 以下という小さな値となり, $f(h \tau)$ は 1 に近い。

$t$ が $t_{0}$ より大きくなると，系は塑性域に入る。系に 供給されるエネルギーと粘性減衰および履歴によって消 費されるエネルギーは釣り合うが, 完全弾塑性履歴の場 合には応答変位が定常になることはない。履歴ループの 中心が原点から移動し，質点は移動した中心のまわりで 振動する。時間 $t^{\prime}\left(\equiv t-t_{0}\right)$ における履歴中心の移動量 を $x_{c}$ ，その中心まわりの変位を $x_{0}$ とすると, 近似的に,

$$
x=x_{\mathrm{c}}+x_{0}
$$

である。 $x_{c}$ は非常に低い振動数をもつ成分， $x_{0}$ はある
等価な固有角振動数 $\omega_{e}$ をもつ成分である。供給された エネルギーは専ら $x_{0}$ に基づく履歴ループと粘性減衰に よって消費される。以後の考察は，とくに断らない限り， $\tau^{\prime}\left(\equiv \tau-\tau_{0}\right) \geqq 0$ の場合についてのものとする。

\section{4. 履歴中心まわりの振動成分}

履歴中心まわりの振動成分 $x_{0}$ を近似的にある等価な 期待固有角振動数 $\omega_{e}$ をもつ正弦振動であるとみなす。 線形減衰の場合, 等価な期待周期 $T_{e}\left(=2 \pi / \omega_{e}\right)$ 当たり のエネルギーの釣合いは,

$$
\bar{x}_{p 1} \alpha+2 h \omega_{0} V_{\dot{x}} \frac{2 \pi}{\omega_{e}}=\pi S_{0} \frac{2 \pi}{\omega_{e}} .
$$

である。ここで, $\bar{x}_{p 1}$ は 1 周期 $T_{e}$ 間での累積塑性変形 の期待值を表す。累積塑性変形とは塑性変形の䋩対値の 総和を表し, 塑性変形とは質点が $f= \pm \alpha$ の線上を移動 する量をいう。 $V$ は分散 $\sigma^{2}$ を表す。

$\dot{x}_{c}$ は $\dot{x}_{0}$ に比へてて分小さいので，(6) 式より $\dot{x}$ は近似的に $\dot{x}_{0}$ に等しい。 $t^{\prime} \geqq 0 て ゙ は \dot{x}_{0}$ は振幅 $\omega_{e}\left(\bar{x}_{p_{1}} / 4+\Delta\right)$ の正弦振動をしている亡みなされるから, .履歴ループがその中心に関して対称で, ループの対角線 の公配が $\omega_{e}^{2}$ に対応するものとすると，

$$
\omega_{e}^{2}=\frac{4 \alpha}{\bar{x}_{\rho 1}+4 \triangle}
$$

である。 $\beta \equiv \omega_{e} / \omega_{0}, \bar{\lambda}_{1} \equiv \bar{x}_{\rho 1} / \Delta$ として（8）式を無次 元表現に改めれば, 次式が得られる。

$$
\beta^{2}=\frac{4}{\bar{\lambda}_{1}+4}
$$

$\dot{x}$ の分散 $V_{\dot{x}}$ は,

$$
V_{\dot{x}}=\frac{\omega_{e}^{2}}{a_{0}^{2}}\left(\frac{\bar{x}_{\rho 1}}{4}+\Delta\right)^{2}
$$

と書ける。ここで， $\tau=\tau_{0}$ における連続性を考虑し，

$$
a_{0}=\sqrt{2} f\left(h \tau_{0}\right)
$$

とする。

（10）式を（7）式の $V_{\dot{x}}$ に代入し，すべての量を無 次元化すれば，次式が得られる。

$$
\bar{\lambda}_{1}=\frac{2 \pi}{\beta^{3}}\left(\pi \beta^{2} \xi-\frac{2 h}{a_{0}^{2}}\right)
$$

(9)，(12）式は $\bar{\lambda}_{1}$ と $\beta$ に関する連立方程式である。こ れを解析的に解くことはできないが，反復計算によって 解を得ることは容易である。

線形減衰の粘性減衰係数に対する非線形減衰の之れの 比は平均的に $\omega_{e}^{2} / \omega_{0}^{2}=\beta^{2}$ であると考えられるから，非 線形減衰の場合には，(12)式の右辺の第 2 項にある $h$ のかわりに平均的に $h \beta^{2}$ を使い, 以下同様にして $\bar{\lambda}_{1}$ と $\beta$ を求めればよい。

このようにして $\beta$ を具体的に求めてみると， $\beta$ が $h$ によりそれほど変化せず，また減衰の型にもあまり依存 しないことがわかる。 
$\dot{\eta} \equiv \dot{x} /\left(\omega_{0} \Delta\right)$ として $(10)$ 式を無次元表現に書き改め, (9) 式を利用すると,

$$
V_{\dot{\eta}}=\frac{1}{a_{0}^{2} \beta^{2}}
$$

となる。娍衰の型に応じて $\beta$ が変わるので， $V_{\dot{n}} も そ れ ~$ に従って変化する。

なお（13）式を使えば，(12）式は,

$$
\dot{\lambda_{1}}=\frac{4 \pi h}{\beta}\left(\frac{\pi \xi}{2 h}-V_{\dot{n}}\right)
$$

と書ける。弾性限界である $\tau^{\prime}=0, \beta=1$ では $(5)$ 式 より, $V_{\dot{n}}=V_{\eta}<\pi \xi /(2 h)$ となることがわかるので, (14) 式の右辺は常に正である。これは，王>0で系が常に弾 塑性域にあることと対応している。

履歷減衰を等価な粘性減衰に置きかえたい場合には， 等価な減衰定数を $h_{e}$ とすると,

$$
\bar{x}_{1} \alpha=2 h_{e} \omega_{e} V_{\dot{x}} \frac{2 \pi}{\omega_{e}}
$$

であるから，これを無次元表現に改めて整理すれば，

$$
h_{e}=\frac{a_{0}^{2} \beta^{2} \bar{\lambda}_{1}}{4 \pi}
$$

となる。この等価減衰定数の值はあとでピークファク 夕一 $p$ を求めるときに使われる。

\section{5. 累積塑性率と減衰エネルギーの期待值と分散}

$t^{\prime} \geqq 0$ における累積塑性変形 $x_{a}$ の期待值は,

$$
\bar{x}_{a}=\bar{x}_{p 1} t^{\prime} \frac{\omega_{e}}{2 \pi}
$$

であるから，上式を無次元化すれば，累積塑性率 $\lambda \equiv x_{a} / \Delta$ の期待値は次のようになる。

$$
\bar{\lambda}=\bar{\lambda}_{1} \beta \tau^{\prime}
$$

$t^{\prime}$ 間で粘性減衰によって消費されるエネルギー $D$ の 無次元量 $\delta \equiv D /(\alpha \Delta)$ の期待値は, 供給される全エネル ギーを $\alpha \Delta$ で除した無次元量 $\varepsilon$ 期待值 $2 \pi^{2} \xi \tau^{\prime}$ から $\bar{\lambda}$ を差し引いたものに等しいから，

$$
\bar{\delta}=\left(2 \pi^{2} \xi-\bar{\lambda}_{1} \beta\right) \tau^{\prime}
$$

（12）式と（13）式からわかるように, 線形減衰の場合 にはこれを次のように書いてもよい。

$$
\bar{\delta}=4 \pi h \tau^{\prime} V_{\dot{\eta}}
$$

このとき，全エネルギ一の期待值に対する履歴吸仪工ネ ルギーの期待值の比は（18）（20）式より，

$$
\frac{\bar{\lambda}}{\bar{\lambda}+\bar{\delta}}=\frac{1}{1+\frac{4 \pi h V_{\dot{n}}}{\bar{\lambda}_{1} \beta}}
$$

となり， $\tau^{\prime}$ に依存しない。非線形減衰の場合には，(20),

(21) 式で $h$ のかわりに $h \beta^{2}$ を入れればよい。

速度応答が振幅 $A$ をもつ角振動数 $\omega_{e}$ の正弦振動をし ているとすると，線形減衰の場合，半周期あたりの減衰 エネルギー $D_{H}$ の期待値は $\left(\pi h \omega_{0} / \omega_{e}\right) \bar{A}^{2}, 2$ 乗平均值は $\left(\pi h \omega_{0} / \omega_{e}\right)^{2} \overline{A^{4}}$ と書けるので， $D_{H}$ の分散は,

$$
\left(\pi h \omega_{0} / \omega_{e}\right)^{2} \cdot\left(\overline{A^{4}}-{\overline{A^{2}}}^{2}\right)
$$

に等しい。速度応答は必ずしも狭帯域のガウス過程では ないが，近似的にそう考えることができれば，振幅 $A$ をレーリー分布をもつ確率変数と仮定できることにな り, 近似的に,

$$
\bar{A}^{4}-{\overline{A^{2}}}^{2}=8 \sigma_{\dot{x}}^{4}-\left(2 \sigma_{\dot{x}}^{2}\right)^{2}=4 \sigma_{\dot{x}}^{4}
$$

である。速度が正の場合の累積塑性変形亡速度が負の場 合の累積塑性変形は互いに独立であるとみなしてょいの で, 大ざっぱに半周期ごとの娍衰エネルギーも互いに独 立であると仮定すると， $t^{\prime}$ 間における减衰エネルギー の分散は近似的に次式で与えられる。

$$
V_{D}=\frac{4 \pi h^{2} \omega_{0}^{2}{ }^{\prime}}{\omega_{e}} V_{\dot{x}}^{2} t^{\prime}
$$

（22）式を無次元化すれば,

$$
V_{\delta}=\frac{8 \pi^{2} h^{2} \tau^{\prime}}{\beta} V_{\dot{n}}^{2}
$$

である。（23）式でも非線形減衰の場合には， $h$ のかわ りに $h \beta^{2}$ を使う。

$\lambda$ と $\delta$ には正の強い相関があると考えられる。確率 変数 $\varepsilon$ が增減すると，それに伴って $\lambda$ と $\delta$ が共に增減 するとみなされるからである。そこで，近似的に $\lambda と \delta$ の間に完全な相関があると仮定すると,

$$
\sigma_{\varepsilon}=\sigma_{\lambda}+\sigma_{\sigma}
$$

である。 $\varepsilon$ の分散は,

$$
V_{\varepsilon}=4 \pi^{2} \xi \tau^{\prime} V_{\dot{n}}
$$

で与えられるから"，(23），(25）式を（24）式に適用 すれば, 線形娍衰の場合,

$$
\sigma_{\lambda}=2 \pi \sqrt{\tau^{\prime}}\left(\sqrt{\xi}-h \sigma_{\dot{\eta}} \sqrt{\frac{2}{\beta}}\right) \sigma_{\dot{\eta}}
$$

となる。（26）式でも非線形減衰の場合には, $h$ のとこ ろに $h \beta^{2}$ を代入すればよい。

\section{6. 变位の分散と塑性率の期待值と分散}

変位の無次元量 $\eta$ の分散は, $\eta_{c}$ と $\eta_{0}$ が確率的に独立 であるという仮定を導入することにより，

$$
V_{n}=V_{\lambda}+\frac{V_{\dot{n}}}{\beta^{2}}
$$

と得られる!。上式の $V_{\lambda} に(26)$ 式を適用すれば, 線 形減衰の場合，具体的に次のように書ける。

$$
V_{n}=\left\{4 \pi^{2} \tau^{\prime}\left(\sqrt{\xi}-h \sigma_{\dot{n}} \sqrt{\frac{2}{\beta}}\right)^{2}+\frac{1}{\beta^{2}}\right\} V_{\dot{n}}
$$

非線形減衰の場合には，hのところに $h \beta^{2}$ を代入する。

塑性率 $\mu$ の期待値は, 同様に $\left|\eta_{c}\right|_{\max }$ 之 $\left|\eta_{0}\right|_{\max }$ が独 立であるとして，

$$
\bar{\mu}=\sqrt{\frac{\pi}{2} V_{\lambda}+\frac{p^{2}}{\beta^{2}} V_{\dot{\eta}}} .
$$

である”。ここで, $p$ はいわゆるピークファクターを表す。 $\tau=\tau_{0}$ における連続性を保つようにし，また塑性領域に 
入ることによって見かけ上堿衰が増加することを考慮す れば, 線形減衰の場合,

$$
\begin{aligned}
& p=\sqrt{2} f\left(h \tau_{0}+\left(h / \beta+h_{e}\right) \beta \tau^{\prime}\right) \\
& =\sqrt{2} f\left(h \tau+\beta h_{e} \tau^{\prime}\right)
\end{aligned}
$$

とすることができる。 $\omega_{0}$ に対応する $h$ を $\omega_{e}$ に対応す るものに変換したのが上式の $h / \beta$ という項である。 $h_{e}$ は（16）式で与えられる。非線形减衰の場合には，上式 で $h$ のころに $h \beta^{2}$ を代入する。

（26）式を用いて（29）式を具体的に書けば,

$$
\bar{\mu}=\sqrt{2 \pi^{3} \tau^{\prime}\left(\sqrt{\xi}-h \sigma_{\dot{\eta}} \sqrt{\frac{2}{\beta}}\right)^{2}+\frac{p^{2}}{\beta^{2}}} \sigma_{\dot{\eta}}
$$

非線形減衰の場合には，上式で $h$ のところを $h \beta^{2}$ とす る。

$\mu$ の分散は近似的に $\left|\eta_{c}\right|_{\text {max }}$ の分散と $\left|\eta_{0}\right|_{\text {max }}$ の分散 の和になるが，後者は前者に比べて十分小さいと考えら れるので1，これを無視すると次式が得られる。

$$
V_{\mu}=\left(2 C-\frac{\pi}{2}\right) V_{\lambda}
$$

ここで, $C$ はカタランの定数で,$C \approx 0.9160$ である。

\section{7. シミュレーションによる検証と考察}

以上の近似的表現式の妥当性を検証するために，モン テカルロ・シミュレーションによる数值実験が行われ た。異なる振動数とランダムな位相をもつ正弦関数を多 数重ね合わせることによってホワイトノイズと同等の特 性をもつサンプルが 300 個作成された1”。それらによる 非定常な非線形応答が数値的に計算され，結果は統計的 に処理された。 $\xi$ の值は $0.025 ， 0.05 ， 0.075,0.10$ の

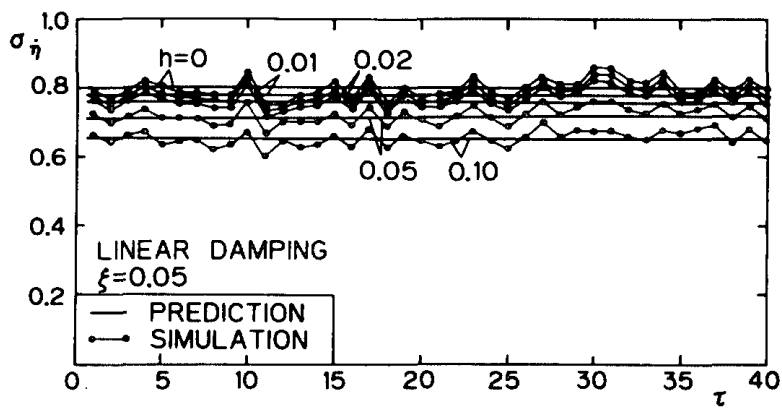

Fig. 1 Time change of standard deviation of velocity

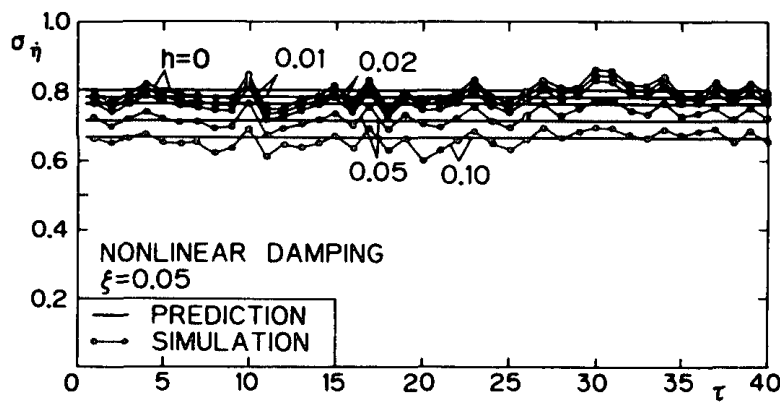

Fig. 2 Time change of standard deviation of velocity $-66-$
4 種類， $h$ の值は，0，0.01，0.02，0.05，0.10の 5 種 類とした。

Figs. 1, 2 に $\sigma_{\dot{\eta}}-\tau$ 関係を示す。前者が線形減衰, 後

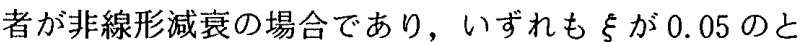
きの例である。この $\xi$ の值は非常に強い地震動をうけ る中低層構造物の典型的なものに相当している。洌えば，

$S_{0}=200 \sim 300 \mathrm{~cm}^{2} \cdot \mathrm{s}^{-3}, \quad T=0.3 \sim 0.5 \mathrm{~s}, \alpha=300 \mathrm{~cm}$. $\mathrm{s}^{-2}$ とすると,

$$
\xi=\frac{2 \pi}{(0.3 \sim 0.5)} \times \frac{(200 \sim 300)}{300^{2}}=0.03 \sim 0.07
$$

という数値が得られる。以後の図でも代表例として多く この場合を示す。5つの実線は近似解で，それぞれ 5 種 類の hに対するものである。それらに近接する細い線 で結ばれた黒丸が数値実験の結果を表す。実線と黒丸は 比較的よく一致している。減衰の型は $\sigma_{\dot{n}}$ の値にあまり 大きな影響を与えない。

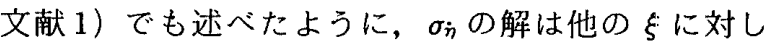
ては必ずしも十分な精度をもたない。乡が小さい場合に 過大評価, $\xi$ が大きい場合に過少評価となる傾向にある。 $\sigma_{\eta}$ は各種の応答量を直接支配する重要な量なので，試 みに数値実験值により合うような実験式を次のように作 成してみた。まず速度応答が十分定常となる範囲， $5 \tau_{0}$ $<\tau \leqq 40$ での $\sigma_{\dot{\eta}}$ の平均值に近似解の $\beta$ を乗じたものを

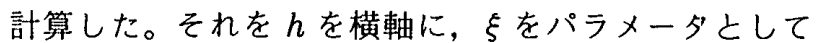
Fig. 3 に黒丸で示す。 $\beta \sigma_{\dot{n}}=1 / a_{0}$ の値は理論的にも数値 上も減衰の型に依存しないので，2つの減衰の型の平均 をとってある。実線は近似解を表し, 黒丸とは必ずしも よく合わないことがわかる。

$\beta \sigma_{\dot{n}}$ は $h$ に対して双曲線状に減少し， $\xi$ に対して直線 状に増加するようにみえる。そこでこれを単純に，

$$
\beta \sigma_{\dot{\eta}}=u \frac{1+v \xi}{1+w h}
$$

とおき, $u, v, w$ の值を最小 2 乗法で求めてみると,

$$
u=0.590, \quad v=3.60, \cdot w=1.42
$$

という值が得られた。これが同図の点線である。こうす れば $\xi の$ 広い範囲でより精度の高い值が得られる。な お文献 1) では, $h=0$ の場合の実用式として次式が提 示されている。

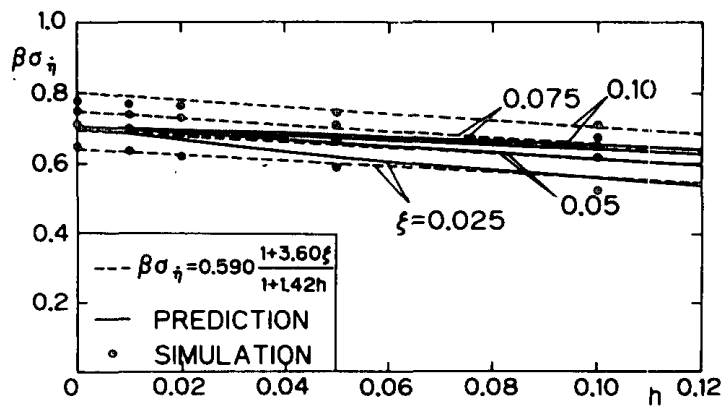

Fig. 3 Semi-empirical expression for standard deviation of velocity 


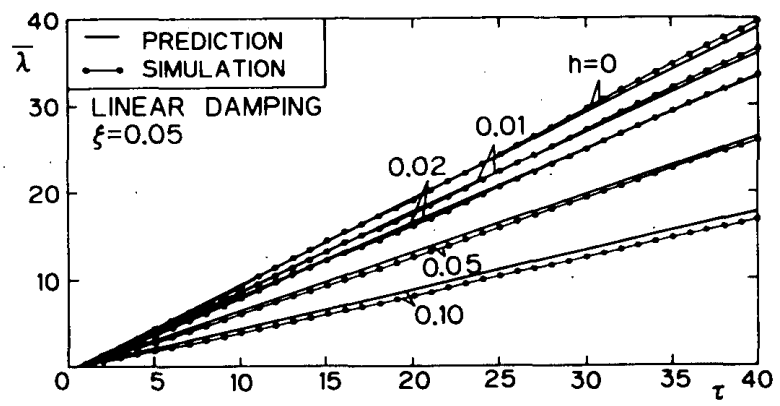

Fig. 4 Time change of expectation of cumulative ductility factor

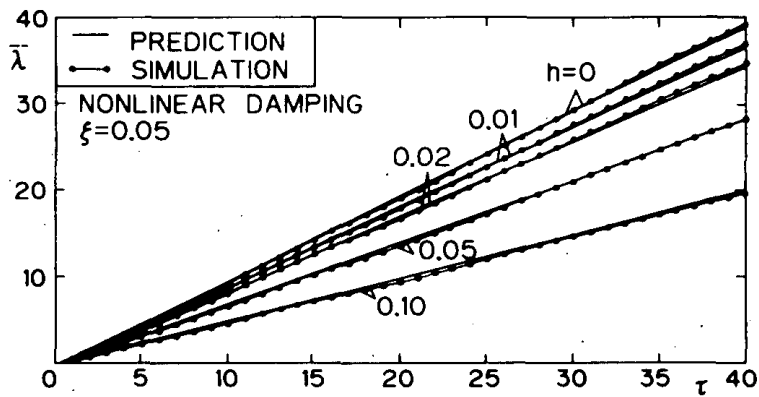

Fig. 5 Time change of expectation of cumulative ductility factor

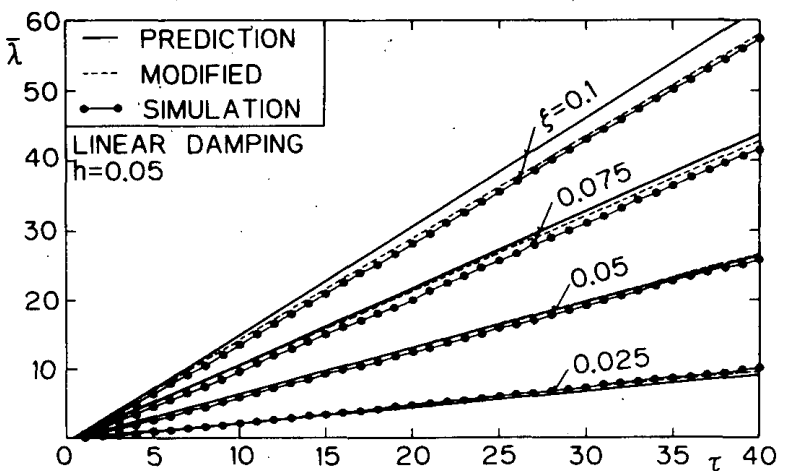

Fig. 6 Time change of expectation of cumulative ductility factor

$\sigma_{\dot{n}}=i \xi+j \beta$

ここで, $i=5.31, \quad j=0.597$

この形式は（33）式と事夷上同等であり，(33)，(34）

式による值と $(35)$. 式による值は $0.25 \leqq \xi \leqq 0.1$ の範囲 で $3 \%$ 以下の相対誤差で一致する。

Figs. $4,5 に \xi=0.05$ の場合の $\bar{\lambda} ー \tau$ 関係を示す。近 似解は数值実験值とよく一致している。他の $\xi$ に対し てどうなるかをみるために，hが 0.05 である線形減衰 の場合の $\xi=0.025 \sim 0.1$ における $\bar{\lambda} 一 \tau$ 関係を Fig. 6 に 示す。 $\xi$ が変化すれば一致の程度も変わるが，試みに $\sigma_{\dot{n}}$ に（33），(34）式を使ってみると，点線のような結 果となり，解の精度が向上することがわかる。

なお，以後の図では $\sigma_{\dot{n}}$ の近似解としてすべて（13） 式によるものを用いている。(33)，(34) 式による $\sigma_{\dot{\eta}}$ を かわりに使えば，他のほに対して一般に解の精度は向

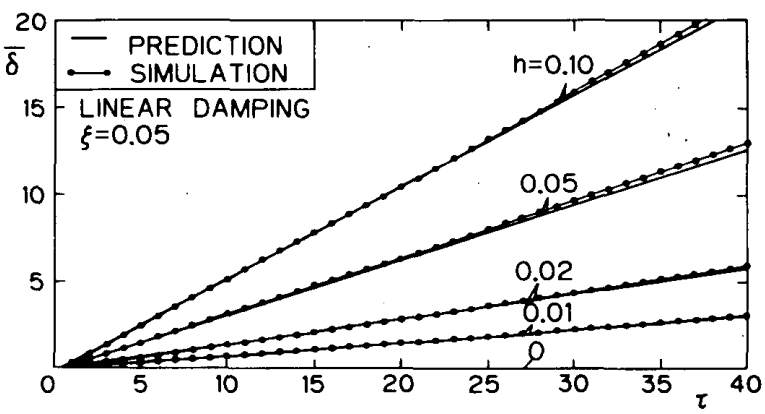

Fig. 7 Time change of expectation of damping energy

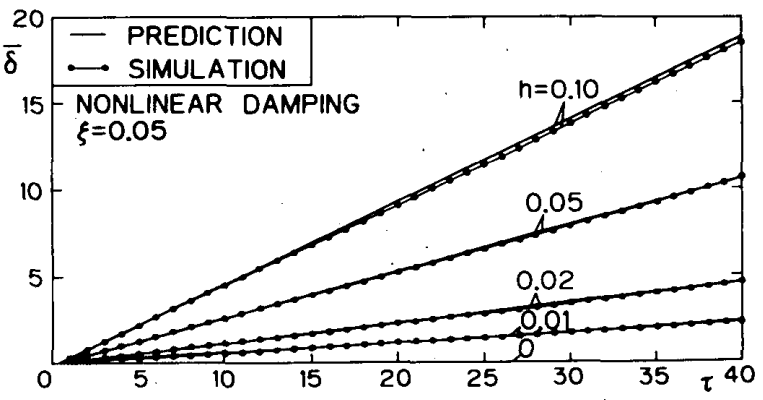

Fig. 8 Time change of expectation of damping energy

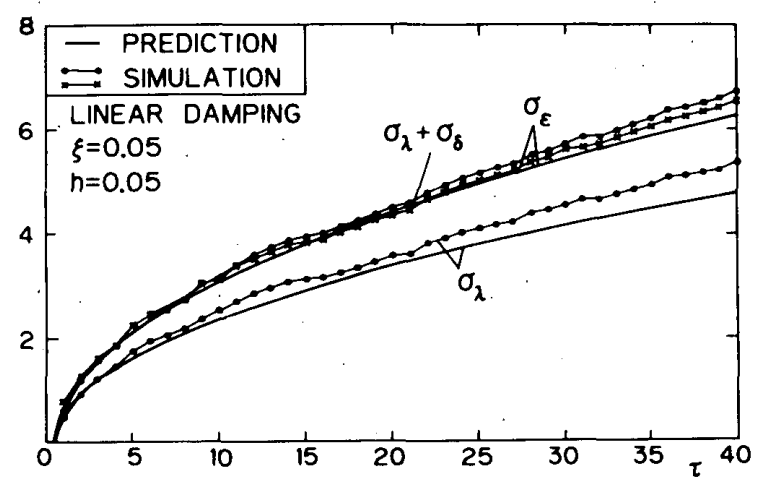

Fig. 9 Comparison of $\sigma_{\varepsilon}$ with $\sigma_{\lambda}+\sigma_{\delta}$

上する。向上する度合いはFig. 3 からわかるように， $h$ が小さいほど大きい。 $h$ がゼロの場合によ゙の程度精度が よくなるかは文献 1) に詳述されているので，このこと についてはその部分を参照していただくこととし，これ 以上の詳細は紙面の都合で割愛する。

Figs.7,8は $\bar{\delta}-\tau$ の関係を示したもので, 近似解と 数値実験值が一致する度合いは満足すべきものである。

$\lambda と \sigma$ 相関が強く，(24）式が近似的に成り立つこ とを検証したのが Fig. 9 である。 $h$ が 0.05 である線形 减衰の場合の例である。(24) 式がよい精度で成立して おり，近似解ともよく一致していることがわかる。図は 省略するが，非線形減衰の場合にも，大体 $(24)$ 式が成 り立ち， $\sigma_{\varepsilon}$ の近似解も数值実験の值とよく一致するこ とが確認できた。

Figs. 10,11に $\sigma_{\lambda}-\tau$ 関係を, Figs. 12, 13 に $\sigma_{\sigma}-\tau$ 


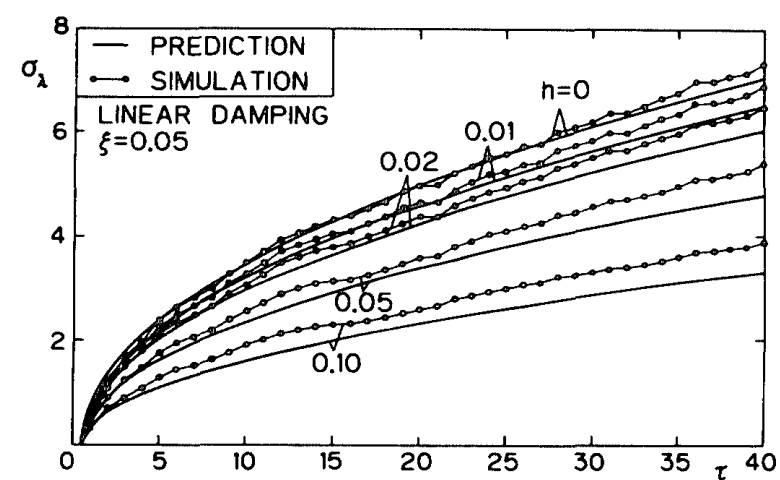

Fig. 10 Time change of standard deviation of cumulative ductility factor

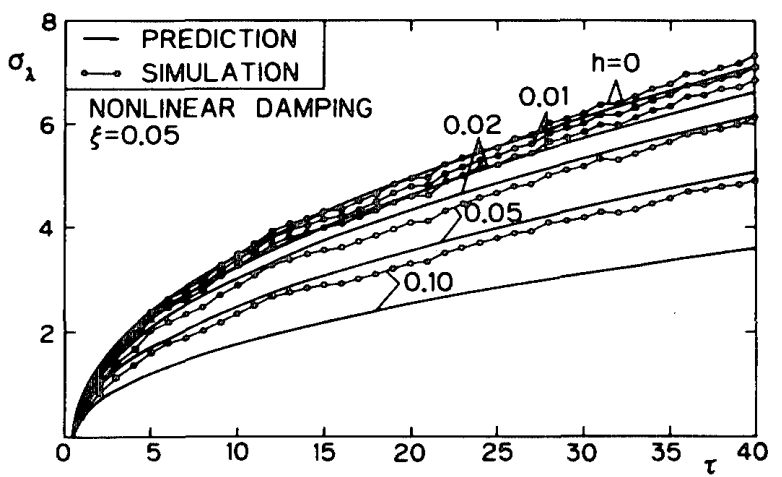

Fig. 11 Time change of standard deviation of cumulative ductility factor

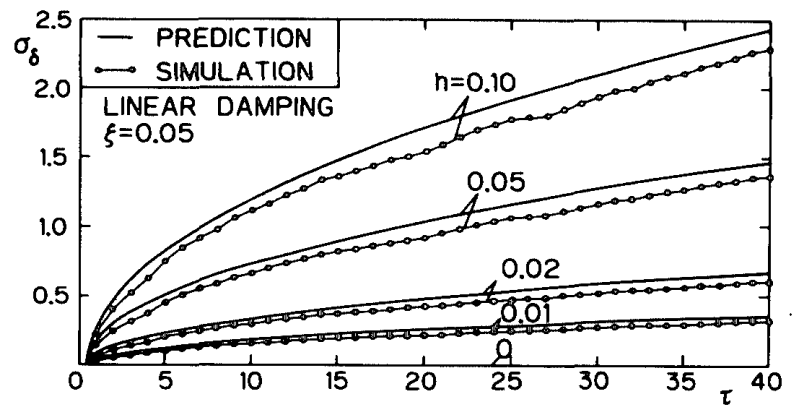

Fig. 12 Time change of standard deviation of damping energy

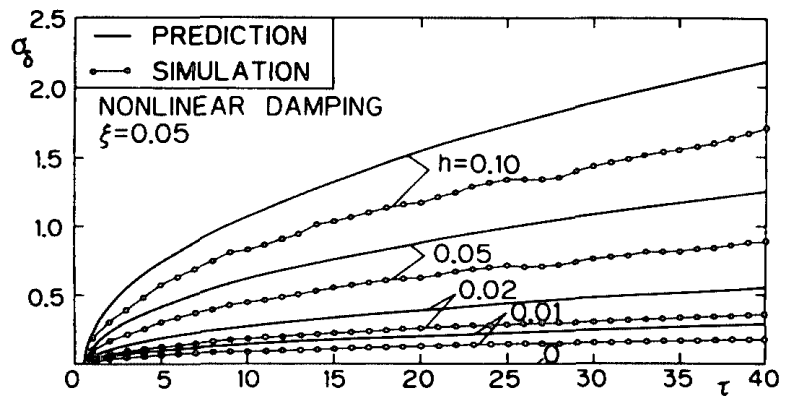

Fig. 13 Time change of standard deviation of damping energy

関係を示す。線形減衰の場合には， $\sigma_{\lambda}, \sigma_{\sigma}$ の近似解が比 較的よい精度をもつことがわかる。非線形減衰の場合に は， $\sigma_{\sigma}$ の近似解がやや過大評価となり，その結果 $\delta_{\lambda}$ の 解が過少評価となっている。

Fig. 14 に線形減衰の場合の $\sigma_{n}-\tau$ 関係を示す。近似 $-68-$

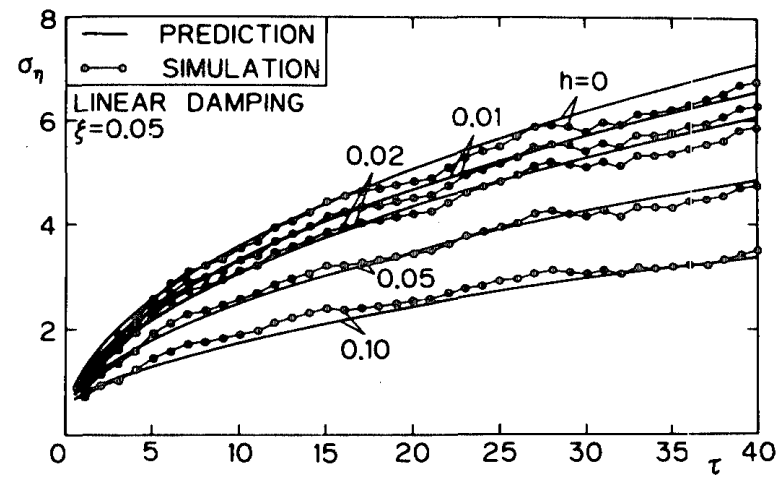

Fig. 14 Time change of standard deviation of displacement

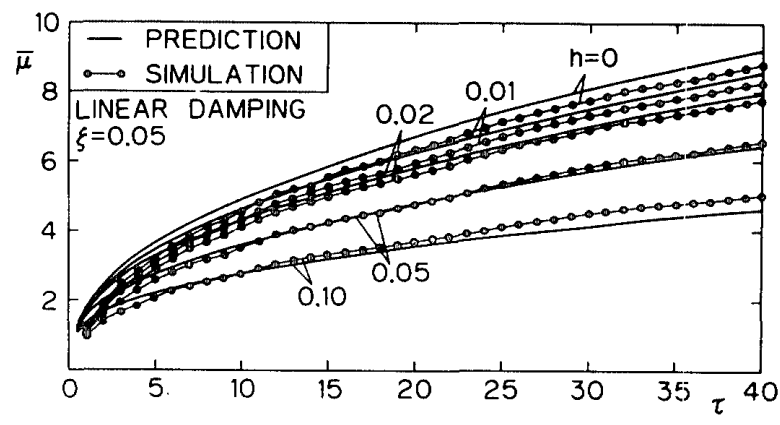

Fig. 15 Time change of expectation of ductility factor

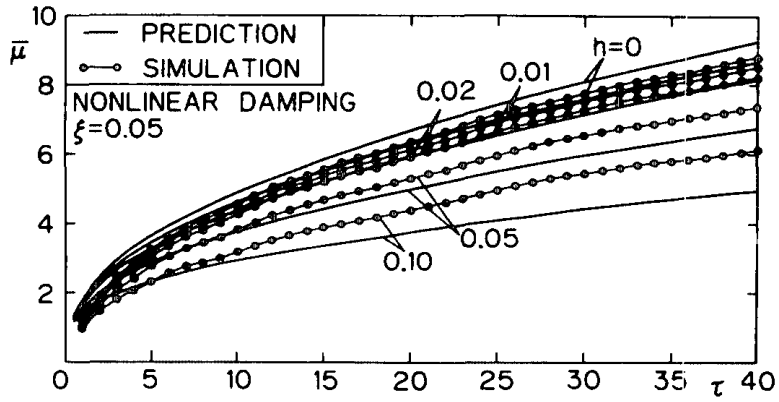

Fig. 16 Time change of expectation of ductility factor

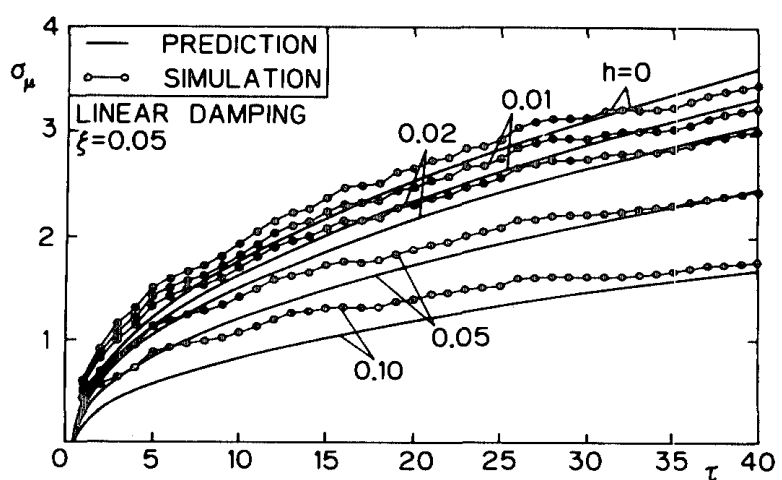

Fig. 17 Time change of standard deviation of ductility factor

解は数値実験值とよく合っている。図は省略するが，非 線形減衰の場合には $h$ が大きいところで解はやや小さ 目の值を与える。

Figs. 15，16に $\bar{\mu}-\tau$ 関係を示す。 $\sigma_{\eta}$ の場合上似た傾 向を指摘することができる。Fig. 17 は線形減衰の場合 
の $\sigma_{\mu}-\tau$ 関係である。

Figs.18, 19 は灭と六の関係を示したものである。線 形減衰の場合には近似解之数值実験值は大体よく合う が，非線形娍衰の場合には両者が一致する度合いはあま りよくない。なお後者の数值実験値では $h$ にる差が 小さく区別するのが困難なので， $h$ との対応は指示され ていない。

非減衰の場合" と同様に，試みに数值実験值が次のよ うな簡単な関係,

$$
\bar{\mu}=b \sqrt{\bar{\lambda}}+1
$$

にあるものとし， $b$ の值を各 $\xi$ と $h$ に対して最小 2 乗 法で求めてみた。使用されたデー夕はそれぞれ $\tau=1,2$, …...,40 の場合の 40 個である。その結果が Figs. 20, 21 に黒丸で示されている。 $b$ は $\xi$ に対して直線状に増 加し， $h$ に対して双曲線状に娍少するので, 更にこれを,

$$
b=c \frac{1+d \xi}{1+e h}
$$

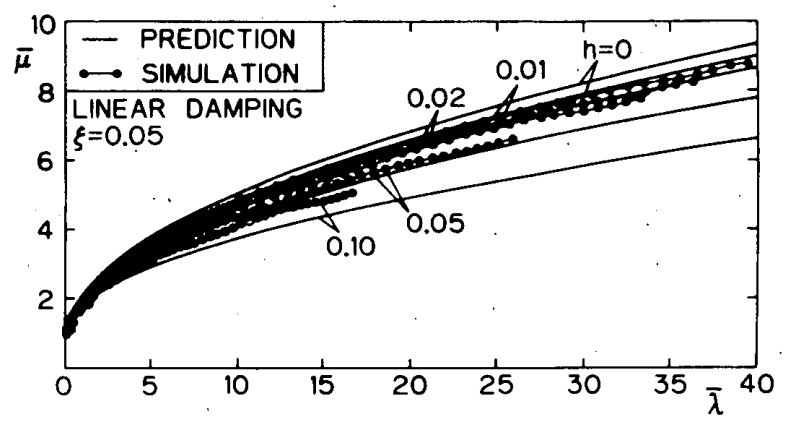

Fig. 18 Relation between expectations of ductility and cumulative ductility factor

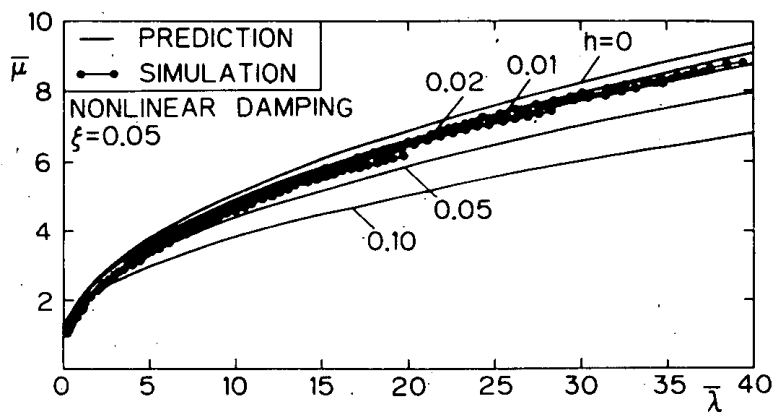

Fig. 19 Relation between expectations of ductility and cumulative ductility factor

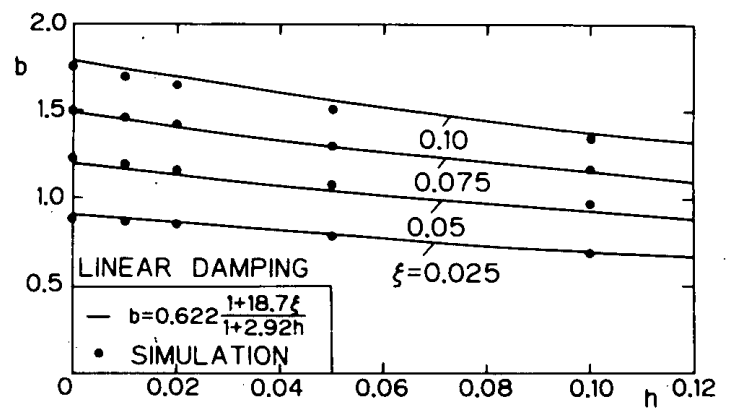

Fig. 20 Coefficient $\mathrm{b}$ appearing in Eq. $\bar{\mu}=b \sqrt{\bar{\lambda}}+1$
と書き表す。両図に示されているデータをすべて使い， 再び最小 2 乗法によって $c, d$ の值を決定すると，

$$
c=0.622, \quad d=18.7
$$

という数值が得られた。また， eの值は線形減衰の場合,

$$
e=2.92
$$

非線形减衰の場合,

$$
e=0.908 \text {. }
$$

となった。(37)～(40) 式による’bの值が同図の夷線で ある。bに与える $h$ の影響は小さく，とくに非線形減 衰の場合にそうである。実用的には，(36)～(40) 式を $\bar{\mu}-\bar{\lambda}$ 関係を表す近似式としてもよい。なお，文献 1) によれば， $h=0$ の場合， $c=0.649, d=17.7$ である。 これと (38) 式によるものとは， $0.025 \leqq \xi \leqq 0.1$ の範囲 で約 $3 \%$ 以下の相対誤差で一致する。このことは， $\xi$ と $h$ が互いに無関係に $b$ に寄与するという（37.) 式の 形が妥当であることを示している。

Figs. 22, 23 に $\sigma_{\mu}$ と $\sigma_{\lambda}$ の関係を示す。 $h$ によ差が

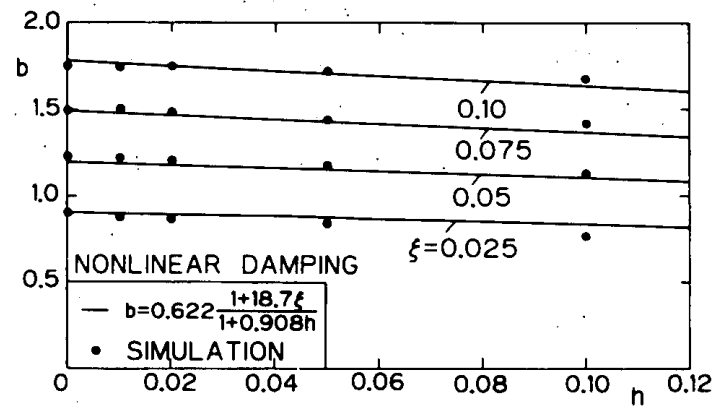

Fig. 21. Coefficient b appearing in Eq. $\bar{\mu}=b \sqrt{\bar{\lambda}}+1$

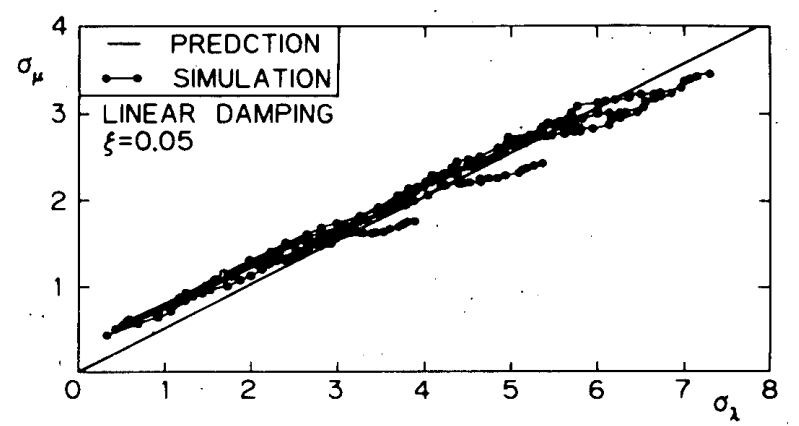

Fig. 22 Relation between standard deviations of ductility and cumulative ductility factor

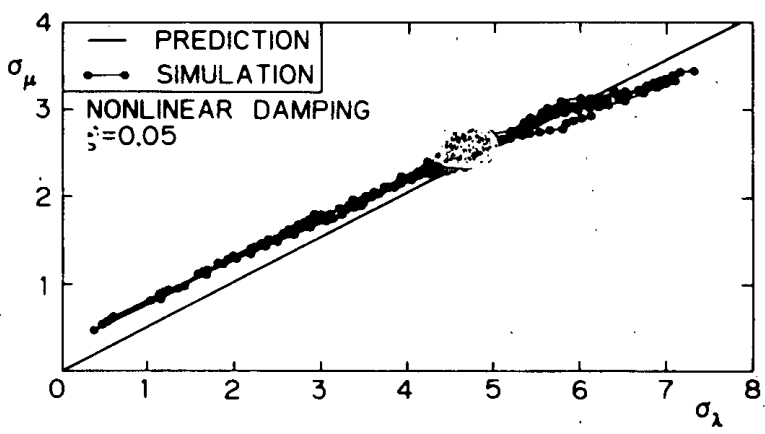

Fig. 23 Relation between standard deviations of ductility and cumulative ductility factor 


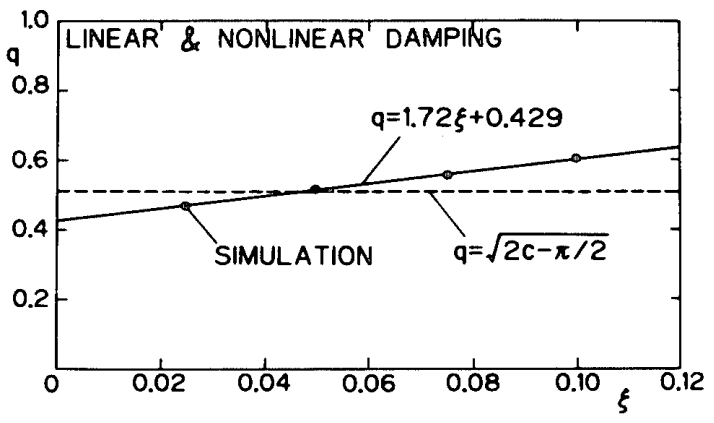

Fig. 24 Coefficient $\mathrm{q}$ appearing in Eq. $\sigma_{\mu}=q \sigma_{\lambda}$

少なく，区別するのが困難なので，数值実験值には $h$ との対応は指示されていない。実線は $h$ に依存しない。 近似解と数值実験値の対応は非常によいとはいえない が，おおむね解は妥当な值を与える。試みに，数值実験 值が次のような簡単な関係,

$$
\sigma_{\mu}=q \sigma_{\lambda}
$$

にあるものとし, 前の場合と同様な手法に従って $q$ の 值を求めてみた。ただし， $q$ は诚衰の型と $h$ には依存 せず，乡にだけよるものとした。その結果が Fig. 24 に 黒丸で示されている。 $q$ は $\xi$ に対して直線状に增加す るので,

$$
q=r \xi+s
$$

と書き表し，同様にパラメータの值を決定すると，

$$
r=1.72, \quad s=0.429
$$

となった。これが同図の実線である。実用的には（41） （43）式を $\sigma_{\mu}-\sigma_{\lambda}$ 関係を表す近似式としてもよい。な お，文献 1）によれば, $h=0$ の場合， $r=2.14, s=$ 0.406 である。これと (41) （43）式によるものとは， $0.025 \leqq \xi \leqq 0.1$ の範囲で約 $3 \%$ 以下の相対誤差で一致

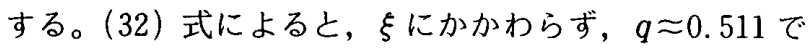
ある。これが点線で示されている。 $\xi$ は $q$ に対してあ まり強いパラメータではないので，この一定值を $q$ の 値と考えても大きな誤りはない。

以上の上うに近似解と数値実験值は多くの場合上く一 致するが，そうともいえない場合もある。そこで，以下 に近似解に含まれる問題点を要約し，より詳細な分析は 将来の課題として残すこととする。

1）非減衰の場合"と同様に， $\sigma_{\dot{n}}$ の近似解は $\xi$ のさい ところで数值実験値よりやや小さ目， $\xi$ の大きいところ でやや大き目の值を与える。その理由は必ずしも明らか でないが， $\sigma_{n}$ の解の精度が他の多くの量を直接支配す るので，その解を理論的に改良することが望まれる。

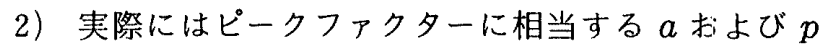
の値をこのように単純に扱うことはできない。数值実験 值で具体的にこの值がどのようになっているかをより詳 細に分析する必要がある。

3） $\sigma_{\sigma}$ を評価するときに, 速度振幅 $A$ がレーリ゙一分布 をもち，半周期ごとの減衰エネルギーが互いに独立であ ると仮定したが，これが実際にどの程度適切であるかを より詳細に検討する必要がある。非線形诚衰の場合に $\sigma_{\sigma}$ の表現が，とくに $h$ が大きいところであまり適切で ない理由もこれに関連して分析すべきである。

4）一般に平均値の解はよい精度をもち問題が少ない が，とくに非線形減衰の場合におけるいくつかの分散の 表現には改良の余地がある。

\section{8. 要約と結び}

粘性減衰をもつ完全弾塑性型のバイリニア履昰特性を もつ 1 自由度系に，ホワイトノイズが地動加速度として 作用した場合の非線形ランダム応答を論じた。粘性減衰 としては弾性剛性比例型と瞬間剛性比例型の 2 種類を想 定した。変位, 速度, 塑性率, 累積塑性率および減衰工 ネルギーの期待値と分散の解析的表現を近似的に求め た。近似解は数値実験値と大体においてよく一致した。 ただし，解を求めるときに導入された仮定にはより詳細 に分析する必要のあるものがある。それに関連してとく にいくつかの分散の表現には改良の余地がある。塑性率 と累積塑性率の関係を一層実用的な形でとりまこめた。 応答は一般に減衰定数の值に強く影響されるが，減衰の 型にはあまり依存しない。

\section{謝 辞}

この論文を作成するのに必要な電算機による計算は, 大和総合研究所の弘中秀之氏（当時筑波大学学生）に負 う。ここに記して感謝する。

\section{参考文献}

1) 松島 豊：バイリニア型履歷をもつ 1 自由度系のランダ 么応答, 日本建築学会構造系論文報告集, 第 420 号, pp. 101 110, 1991. 2.

2) Rosenblueth, E. and Bustamante, J. I. : Distribution of Structural Response to Earthquakes, Journal of the Engineering Mechanics Division, ASCE, EM 3, pp. 75 $\sim 106,1962.6$.

(1991 年 10 月 28 日原稿受理, 1992 年 4 月 2 日採用決定) 